\title{
THE RELATIONSHIP BETWEEN NUMERICAL ABILITY, INDEPENDENCE LEARNING, AND PARENT'S ATTENTION WITH MATHEMATICS LEARNING OUTCOMES IN STUDENTS MTS MUHAMMADIYAH KARANGKAJEN
}

\author{
Hasanatul Fu'adah Amran ${ }^{a}$, Sumargiyani ${ }^{b}$ \\ Program Studi Pendidikan Matematika Universitas Ahmad Dahlan \\ Jalan Ring Road Selatan, Tamanan, Banguntapan, Bantul Yogyakarta

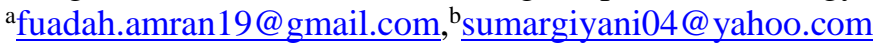

\begin{abstract}
The result of low mathematics learning related to several factors. The relationship between numerical skills, independent learning, and parent's attention are the factors that may be linked to learning outcomes. The research is intended to know about is there any positive correlation and significance or not between numerical ability, independence learning, and parent's attention with mathematics learning outcomes in students class VII in odd semester of MTs Muhammadiyah Karangkajen Yogyakartar in the academic year of 2016/2017. The population in this research was the students of VII grade in MTs Muhammadiyah Karangkajen Yogyakartar in the academic year of 2016/2017, consisted of class VIIA, VIIB, VIIC, VIID, and VIII, totaling 150 students. Samples were taken from VIIE as the research sample class and with the random sampling technique. The writer uses a questionnaire method to collect the data of independent learning and parent's attention, and test method to get the numerical ability and result learning of math. The research instrument: validity test, different power test, and reliability test. Test requirement analysis includes a test of normality, a test of linearity, and the test of independence. The writer uses product-moment correlation analysis and multiple linear regression analysis to analyze the data. The results showed that there was a positive and significant relationship between numerical ability, independence learning, and parent's attention with mathematics learning outcomes in students class VII in e odd semester of MTs Muhammadiyah Karangkajen Yogyakartar in the academic year of 2016/2017. It is showed by $\mathrm{F}_{\text {count }}>\mathrm{F}_{\text {table }}$ is $7,4503>2,9912$ with $\mathrm{R}=0,6870$ and $\mathrm{R}^{2}=0,4720$ with $\hat{Y}=-36,0657+$ $0,3258 X_{1}+0,2120 X_{2}+0,52897 X_{3}$, with $\mathrm{SR} X_{1}=55,2710 \%$, SR $X_{2}=9,1814 \%$ and SR $X_{3}=$ $35,5476 \%, \mathrm{SE} \mathrm{X}_{1}=26,0894 \%, \mathrm{SE} \mathrm{X}_{2}=4,3339 \%$ and $\mathrm{SE} \mathrm{X}_{3}=16,7794 \%$.
\end{abstract}

Keywords: $\quad$ Numerical Ability, Independence Learning, Parent's Attention, Mathematics Learning Outcomes.

\section{INTRODUCTION}

Education plays an important role in improving the quality of resources and realizing the ideals of the nation in the intellectual life of this Indonesian nation. Efforts to improve the quality of resources and educate the nation's life are carried out through education. Quality education will produce quality, superior, and competitive human resources. Education also functions and aims to build a national society that has a smart personality, can develop potential, has good character, is capable, creative and responsible. One of the most important and related sciences in human life is mathematics. Mathematics is a universal science that underlies the development of modern technology and can be said to be all science, has an important role in various disciplines and advances the human mind. Therefore, mathematics needs to be taught at every level of education in Indonesia, starting from Elementary School (SD) to the level of Middle School (SMA).

Learning success is caused by several factors but can be classified into two groups, namely internal factors and external factors (Slameto, 2010: 54-55). Internal factors are the factors contained in the student include intelligence, numeracy skills, independence, interest, and motivation. While external factors are factors that exist outside the student's self including the environment, the attention of parents, facilities and infrastructure and others. One of the internal factors that influence student learning outcomes in numeracy. In learning mathematics, numeracy is something that every student needs to have. Numerical ability is a mathematical ability that contains the abilities to work on stat operations and mathematical symbols that are related to accuracy and accuracy in their calculations. With the numerical ability possessed, students will make it easier to solve problems related to numbers and stats. In addition to numerical abilities, student 
learning independence will also affect the student's learning outcomes. Independence is one of the internal factors that come from within students. The independence of learning is very important for every student to improve their learning outcomes. Students' success in learning is determined by themselves. A student who has good learning independence will be able to face all the difficulties he will face in learning activities. Besides, students with good learning independence will be able to solve the problems they face themselves without asking for help from others.

In addition to the internal factors above, there are also external factors that will affect student learning outcomes. One such external factor is the attention of parents. Parents as the first figure responsible for education and the development of children's personalities play a very large role in the results of student mathematics learning. Parents must be able to monitor the learning process of their children properly. Support from parents must also be there because most of the time students are more at home.

The problems in this study are: 1) Is there a positive and significant relationship between numerical abilities and the mathematics learning outcomes of seventh-semester students of the MTs Muhammadiyah Karangkajen in the 2016/2017 academic year? 2) Is there a positive and significant relationship between learning independence and the mathematics learning outcomes of seventh-semester students of the MTs Muhammadiyah Karangkajen in the 2016/2017 school year? 3) Is there a positive and significant relationship between the attention of parents and the results of mathematics learning in seventh-semester students of the MTs Muhammadiyah Karangkajen in the 2016/2017 academic year? 4) Is there a positive and significant relationship between the numerical ability of independent learning and the mathematics learning outcomes of seventh-semester students of the MTs Muhammadiyah Karangkajen in the academic year 2016/2017? 5) Is there a positive and significant relationship between the numerical ability and attention of parents with the results of mathematics learning in seventh-semester students of the MTs Muhammadiyah Karangkajen in the 2016/2017 academic year? 6) Is there a positive and significant relationship between learning independence and the attention of parents with the results of mathematics learning in seventh-semester students of the MTs Muhammadiyah Karangkajen in the 2016/2017 school year? 7) Is there a positive and significant relationship between numerical ability, learning independence, and parents' attention to the mathematics learning outcomes of seventh-semester students of the MTs Muhammadiyah Karangkajen in the 2016/2017 academic year?

The purpose of this study are: 1) To find out whether there is a positive or significant relationship between numerical ability and the mathematics learning outcomes of seventh semester students of the MTs Muhammadiyah Karangkajen in the 2016/2017 academic year, 2) To find out whether there is a relationship or not positive and significant between learning independence and the mathematics learning outcomes of seventh semester students of the MTs Muhammadiyah Karangkajen in the 2016/2017 academic year, 3) To find out whether there is a positive or significant relationship between the attention of parents and the mathematics learning outcomes of class VII students odd semester of MTs Muhammadiyah Karangkajen 2016/2017 academic year, 4) To find out whether there is a positive or significant relationship between numerical ability and independence of learning with the mathematics learning outcomes of seventh semester students of the MTs Muhammadiyah Karangkajen in Yogyakarta in the academic year 2016/2017 5) To find out the existence or absence of a positive and significant relationship between numerical ability and attention of parents with the mathematics learning outcomes of seventh grade students of the semester of MTs Muhammadiyah Karangkajen Yogyakarta, 2016/2017 academic year, 6) To find out whether there is a positive or significant relationship between learning independence and the attention of parents with the mathematics learning outcomes of seventh semester students of the MTs Muhammadiyah Karangkajen in the 2016/2017 academic year, 7) To find out whether there is a positive or significant relationship between numerical abilities, learning independence and parental attention with Mathematics learning outcomes of seventh semester students of the MTs Muhammadiyah Karangkajen in the 2016/2017 academic year. 


\section{THEORY}

According to Fudyantarta, Ki (2010: 68) numerical ability is the ability to understand numerical relationships and solve problems related to number concepts. Meanwhile, according to Bismo, quoted by Indarwati, Retno (2015), said that numerical ability is a person's ability to formulate mathematical problems so that they can be solved by arithmetic operations or ordinary arithmetic, which are added, less, times and divided. According to Nurhayati, Eti (2011: 132) independence is a situation where a person has a competitive desire to advance for the good of himself, can make decisions, take the initiative to overcome problems, have confidence in doing tasks, and be responsible for what do it. According to Kozma, Belle and Williams in Nurhayati, Eti (2011: 141) learning independence is a form of learning that provides opportunities for learners to set goals, sources, and learning activities according to their own needs. Attention according to Slameto (2010: 105) is an activity carried out by someone about the selection of stimuli that come from their environment. The form of parental attention to children's learning according to Walgito, Bimo (2005: 154-155) is to provide a place of learning and learning tools, creating a comfortable learning atmosphere, paying attention to learning time, paying attention to child interaction.

\section{METHODS}

This research is classified as quantitative research. This study uses a form of research design in the form of a Model of the Linkages between Three Free Variables and Bound Variables (Sugiyono, 2010: 11). In this study using one class, namely the sample class. The population in this study were all seventh graders of the MTs Muhammadiyah Karangkajen semester of the 2016/2017 academic year which consisted of 5 classes with a total of 150 students. While the sample in this study was class VII E. The sampling technique used is the Random Sampling of the class. Data collection techniques used were questionnaire techniques with instruments in the form of questionnaires and test techniques in the form of objective questions of multiple-choice forms. Test of prerequisite analysis with normality test with Chisquare formula, linearity test of F-test formula and test of independence of Chi-square formula. The research hypothesis test uses a simple correlation test, multiple regression analysis and multiple linear regression tests with three independent variables. The research hypothesis test uses a simple correlation test to determine whether or not there is a positive and significant relationship between 1) numerical ability with students' mathematics learning outcomes, 2) learning independence with students' mathematics learning outcomes, 3) parents' attention to mathematics learning outcomes students. Furthermore, the research hypothesis test using a multiple regression analysis tests was conducted to determine the presence or absence of a positive and significant relationship between 1) numerical ability and independence of learning with student mathematics learning outcomes, 2) numerical abilities and attention of parents with student mathematics learning outcomes, 3) learning independence and parents 'attention to students' mathematics learning outcomes. While the multiple linear regression test with three independent variables was conducted to find out whether there was a positive or significant relationship between numerical abilities, learning independence and parents 'attention to the students' mathematics learning outcomes.

\section{RESULTS}

\section{Prerequisite Test for Regression Analysis}

\section{a. Normality test}

The summary of the results of the normality test can be seen in Table 1 .

Table 1. Summary of Normality Test Results

\begin{tabular}{|c|c|c|c|c|}
\hline Variable & $\boldsymbol{\chi}^{\mathbf{2}}$ count & $\boldsymbol{\chi}_{\text {table }}^{\mathbf{2}}$ & $\mathbf{d f}$ & Ket \\
\hline $\mathrm{X}_{1}$ & 7,6135 & 7,8147 & 3 & Normal \\
\hline $\mathrm{X}_{2}$ & 0,9558 & 5,5910 & 2 & Normal \\
\hline $\mathrm{X}_{3}$ & 0,5296 & 5,5910 & 2 & Normal \\
\hline $\mathrm{Y}$ & 4,7976 & 5,5910 & 2 & Normal \\
\hline
\end{tabular}

From the normality test at a significant level, $5 \%$ is seen $\chi^{2}$ count $\leq \chi^{2}$ table, this means that the distribution of data obtained in each variable is normally distributed. 


\section{b. Independence Test}

The summary of the independence test results can be seen in Table 2 .

Table 2. Summary of Independence Test Results

\begin{tabular}{|c|c|c|c|}
\hline Variable & $\boldsymbol{\chi}^{\mathbf{2}}$ count & $\boldsymbol{\chi}_{\text {table }}$ & df \\
\hline $\mathrm{X}_{1}$ and $\mathrm{X}_{2}$ & 21,256 & 37,652 & 25 \\
\hline $\mathrm{X}_{1}$ and $\mathrm{X}_{3}$ & 21,803 & 37,652 & 25 \\
\hline $\mathrm{X}_{2}$ and $\mathrm{X}_{3}$ & 26,317 & 37,652 & 25 \\
\hline
\end{tabular}

From the independence test at a significant level of $5 \%(\alpha=0.05)$ and the degree of freedom (df) $=\mathrm{k}-1)(\mathrm{b}-1)$ seen $\chi^{2}$ count $\leq \chi^{2}$ table, this means that the distribution of data obtained on each variable is mutually independent.

\section{c. Linearity Test}

The summary of linearity test results can be seen in Table 3 .

Table 3. Summary of Linearity Test Results

\begin{tabular}{|l|c|c|}
\hline Variable & $\mathbf{F}_{\text {count }}$ & $\mathbf{F}_{\text {table }}$ \\
\hline $\mathrm{X}_{1}$ and $\mathrm{Y}$ & $-0,2154$ & 2,5140 \\
\hline $\mathrm{X}_{2}$ and $\mathrm{Y}$ & 0,5488 & 2,6169 \\
\hline $\mathrm{X}_{3}$ and $\mathrm{Y}$ & 1,4090 & 2,7009 \\
\hline
\end{tabular}

From the linearity test at a significant level of $5 \%(\alpha=0.05)$ and the degrees of freedom $\mathrm{v}_{1}$ numerator $\mathrm{k}-2$ and $\mathrm{v}_{2}$ the denominator $\mathrm{n}-\mathrm{k}$ is seen $\left.\mathrm{F}_{\text {count }} \leq \mathrm{F}_{\text {table }}(1-\alpha)(\mathrm{k}-2, \mathrm{~N}-\mathrm{k})\right)$, this means that there is a linear relationship between the independent variable $(\mathrm{X})$ and the dependent variable $(\mathrm{Y})$.

\section{Hypothesis testing}

\section{a. First hypothesis}

The summary of the results of the first hypothesis test can be seen in Table 4.

Table 4. Summary of First Hypothesis Test Results

\begin{tabular}{|c|c|c|c|}
\hline $\boldsymbol{t}_{\text {count }}$ & $\boldsymbol{t}_{\text {table }}$ & $\mathbf{d f}$ & Info \\
\hline 3,3735 & 2,0518 & 27 & $\begin{array}{c}\mathrm{H}_{0} \text { is rejected, } \\
\mathrm{H}_{1} \text { is accepted }\end{array}$ \\
\hline
\end{tabular}

From the first hypothesis test at a significant level of $5 \%$ and $\mathrm{df}=27$, it can be seen that From the first hypothesis test at a significant level of $5 \%$ and $\mathrm{df}=27$, it can be seen that $t_{\text {count }}=3,3735$ and $t_{\text {table }}=2,0518$ so $t_{\text {count }}>t_{\text {table }}$ This means that there is a positive and significant relationship between numerical ability and the mathematics learning outcomes of seventhsemester students of the MTs Muhammadiyah Karangkajen in the 2016/2017 academic year.

b. Second hypothesis

The summary of the results of the second hypothesis test can be seen in Table 5 .

Table 5. Summary of the Results of the Second Hypothesis Test

\begin{tabular}{|c|c|c|c|}
\hline $\boldsymbol{t}_{\text {count }}$ & $\boldsymbol{t}_{\text {table }}$ & Df & Info \\
\hline 2,1148 & 2,0518 & 27 & $\begin{array}{c}\mathrm{H}_{0} \text { is rejected, } \\
\mathrm{H}_{1} \text { is accepted }\end{array}$ \\
\hline
\end{tabular}

From the second hypothesis test at a significant level of $5 \%$ and $\mathrm{df}=27$, it can be seen that $t_{\text {count }}=2,1148$ and $t_{\text {table }}=2,0518$ so $t_{\text {count }}>t_{\text {table }}$ This means that there is a positive and significant relationship between learning independence and the mathematics learning outcomes of seventh-semester students of the MTs Muhammadiyah Karangkajen in the 2016/2017 academic year.

\section{c. Third hypothesis}

The summary of the results of the third hypothesis test can be seen in Table 6 . 
Table 6. Summary of Third Hypothesis Test Results

\begin{tabular}{|c|c|c|c|}
\hline $\boldsymbol{t}_{\text {count }}$ & $\boldsymbol{t}_{\text {table }}$ & Df & Info \\
\hline 2,8301 & 2,0518 & 27 & $\begin{array}{l}\mathrm{H}_{0} \text { is rejected, } \\
\mathrm{H}_{1} \text { is accepted }\end{array}$ \\
\hline
\end{tabular}

From the third hypothesis test at a significant level of $5 \%$ and $\mathrm{df}=31$, it can be seen that $t_{\text {count }}=$ 2,8301 and $t_{\text {table }}=2,0518$ so $t_{\text {count }}>t_{\text {table }}$ This means there is a positive and significant relationship between the attention of parents with the mathematics learning outcomes of seventhsemester students of the MTs Muhammadiyah Karangkajen in the 2016/2017 academic year.

d. Fourth Hypothesis

The summary of the results of the fourth hypothesis test can be seen in Table 7.

Table 7. Summary of Test Results of the Fourth Hypothesis

\begin{tabular}{|c|c|c|c|}
\hline $\boldsymbol{F}_{\text {count }}$ & $\boldsymbol{F}_{\text {table }}$ & Df & Info \\
\hline 8,0872 & 3,3690 & $\begin{array}{c}v_{1}=2 \\
v_{2}=26\end{array}$ & $\begin{array}{c}\mathrm{H}_{0} \text { is rejected, } \\
\mathrm{H}_{1} \text { is accepted }\end{array}$ \\
\hline
\end{tabular}

From the fourth hypothesis test at a significant level of $5 \%, \mathrm{v}_{1}$ the numerator $=2$ and $\mathrm{v}_{2}$ denominator $=26$ so that it can be obtained $F_{\text {count }}=8,0872$ and $F_{\text {table }}=3,3690$ so $F_{\text {count }} \geq$ $F_{\text {table }}$ This means that there is a positive and significant relationship between numerical ability and independence of learning with the mathematics learning outcomes of seventh-semester students of the MTs Muhammadiyah Karangkajen in the 2016/2017 academic year.

e. Fifth Hypothesis

The summary of the results of the fifth hypothesis test can be seen in Table 8 .

Table 8. Summary of the Results of the Fifth Hypothesis

\begin{tabular}{|c|c|c|c|}
\hline $\boldsymbol{F}_{\text {count }}$ & $\boldsymbol{F}_{\text {table }}$ & Df & Info \\
\hline 11,2308 & 3,3690 & $\begin{array}{c}v_{1}=2 \\
v_{2}=26\end{array}$ & $\begin{array}{c}\mathrm{H}_{0} \text { is rejected, } \\
\mathrm{H}_{1} \text { is accepted }\end{array}$ \\
\hline
\end{tabular}

From the fifth hypothesis test at a significant level of $5 \%$, the $\mathrm{v}_{1}$ numerator $=2$ and $\mathrm{v}_{2}$ denominator $=26$ so that it can be obtained $F_{\text {count }}=11,2308$ and $F_{\text {table }}=3,3690$ so $F_{\text {count }} \geq F_{\text {table }}$ This means there is a positive and significant relationship between the numerical ability and attention of parents with the results of mathematics learning in seventh-grade students of the odd semester of the MTs Muhammadiyah Karangkajen in the 2016/2017 academic year.

\section{f. Sixth Hypothesis}

The summary of the results of the sixth hypothesis test can be seen in Table 9.

Table 9. Summary of Results of the Sixth Hypothesis

\begin{tabular}{|c|c|c|c|}
\hline $\boldsymbol{F}_{\text {count }}$ & $\boldsymbol{F}_{\text {table }}$ & Dk & Info \\
\hline 4,3271 & 3,3690 & $\begin{array}{c}v_{1}=2 \\
v_{2}=26\end{array}$ & $\begin{array}{l}\mathrm{H}_{0} \text { is rejected, } \\
\mathrm{H}_{1} \text { is accepted }\end{array}$ \\
\hline
\end{tabular}

From the sixth hypothesis test at a significant level of $5 \%$, the $\mathrm{v}_{1}$ numerator $=2$ and $\mathrm{v}_{2}$ denominator $=26$ so that it can be obtained $F_{\text {count }}=4,3271$ and $F_{\text {table }}=3,3690$ so $F_{\text {count }} \geq F_{\text {table }}$ This means there is a positive and significant relationship between learning independence and the attention of parents with the results of mathematics learning in seventh-grade students of the odd semester of the Muhammadiyah Karangkajen MTs in the academic year 2016/2017.

\section{g. Seventh Hypothesis}

The summary of the results of the seventh hypothesis test can be seen in Table 10 . 
Table 10. Summary of the Seventh Hypothesis Test Results

\begin{tabular}{|c|c|c|c|}
\hline $\boldsymbol{F}_{\text {count }}$ & $\boldsymbol{F}_{\text {table }}$ & Df & Info \\
\hline 7,4503 & 2,9912 & $v_{1}=3$ & $\mathrm{H}_{0}$ is rejected, \\
& & $v_{2}=25$ & $\mathrm{H}_{1}$ is accepted \\
\hline
\end{tabular}

From the seventh hypothesis test at a significant level of 5\%, $\mathrm{v}_{1}$ numerator $=3$ and $\mathrm{v}_{2}$ denominator $=25$ so that it can be obtained $F_{\text {count }}=7,4503$ and $F_{\text {table }}=2,9912$ so $F_{\text {count }} \geq F_{\text {table }}$ This means that there is a positive and significant relationship between numerical ability, learning independence and the attention of parents with the results of mathematics learning in seventhgrade students of the odd semester of the MTs Muhammadiyah Karangkajen in the academic year $2016 / 2017$.

\section{CONCLUSION}

Based on the analysis of the experimental data and the discussion, this activity concludes the following:

1. There is a positive and significant relationship between numerical ability and the results of mathematics learning for seventh-grade students of Muhammadiyah Karangkajen MTs in the semester of the 2016/2017 academic year. This is indicated by the t-test, namely $t_{\text {count }}>t_{\text {table }}$ or $3,3735>2,0518$. The simple correlation coefficient $(r)$ between numerical abilities and mathematics learning outcomes is 0.5445 . As well as a simple regression equation $\mathrm{Y}$ over $\mathrm{X}_{1}$ is $\hat{Y}=$ $33,6050+0,3703 \mathrm{X}_{1}$.

2. There is a positive and significant relationship between independence of learning and the results of mathematics learning for seventh-grade students of Muhammadiyah Karangkajen MTs in the semester of 2016/2017 academic year. This is indicated by the t-test, namely $t_{\text {count }}>t_{\text {table }}$ or $2,1148>2,0518$. The simple correlation coefficient ( $r$ ) between learning independence and mathematics learning outcomes is 0.3770 . Also, obtained a simple regression equation $\mathrm{Y}$ over $\mathrm{X}_{2}$ is $\widehat{Y}=3,1503+0,6951 \mathrm{X}_{2}$.

3. There is a positive and significant relationship between the attention of parents of students with the results of mathematics learning for seventh-grade students of Muhammadiyah Karangkajen MTs in the odd semester of the 2016/2017 academic year. This is indicated by the t-test, namely $t_{\text {count }}>$ $t_{\text {table }}$ or 2,8301 $>2,0518$. The simple correlation coefficient ( $\mathrm{r}$ ) between the attention of parents with mathematics learning outcomes of 0.4783 . Besides, also obtained a simple regression equation $\mathrm{Y}$ on $\mathrm{X}_{3}$ is $\hat{Y}=-17,9832+0,7212 \mathrm{X}_{3}$.

4. There is a positive and significant relationship between numerical ability and learning independence with the results of mathematics learning for seventh-grade students of MTs Muhammadiyah Karangkajen in the odd semester of the 2016/2017 academic year. This is indicated by the F test, namely $F_{\text {count }}>F_{\text {table }}$ or 8,0872 > 3,3690 Multiple correlation coefficient $(\mathrm{R})$ between numerical ability and independence of learning with mathematical learning outcomes of 0.6193 and coefficient of determination $\left(\mathrm{R}^{2}\right)$ of 0.3835 with linear line equations $\hat{Y}=-7,8605+0,3383 \mathrm{X}_{1}+$ $0,5507 X_{2}$. The relative contribution amount $X_{1}$ is equal to $70,6428 \%$ and $X_{2}$ equal to $29,3572 \%$ and effective contribution $\mathrm{X}_{1}$ equal to $27,0923 \%$ and $\mathrm{X}_{2}$ equal to $11,2588 \%$.

5. There is a positive and significant relationship between numerical abilities and the attention of parents of students with the results of mathematics learning for seventh-grade students of MTs Muhammadiyah Karangkajen in the odd semester of the 2016/2017 academic year. This is indicated by the test $F$ is that $F_{\text {count }}>F_{\text {table }}$ or 11,2308 $>3,3690$. Correlation coefficient (R) between numerical ability and attention of parents with mathematics learning outcomes of 0.6808 and coefficient of determination $\left(\mathrm{R}^{2}\right)$ of 0.4635 with linear line equations $\hat{Y}=-29,5368+0,3325 X_{1}+$ 
$0,6218 X_{3}$. The relative contribution amount $X_{1}$ is equal to $57,4417 \%$ and $X_{3}$ equal to $42,5583 \%$ and effective contribution $\mathrm{X}_{1}$ equal to $26,6238 \%$ and $\mathrm{X}_{3}$ equal to $19,7254 \%$.

6. There is a positive and significant relationship between learning independence and the attention of parents of students with the results of mathematics learning in class VII MTs Muhammadiyah Karangkajen in the odd semester of the 2016/2017 academic year. This is indicated by the F test, namely $F_{\text {count }}>F_{\text {table }}$ or $4,3271>3,3690$. The correlation coefficient (R) between learning independence and the attention of parents with mathematics learning outcomes is 0.4997 and the coefficient of determination $\left(\mathrm{R}^{2}\right)$ is 0.2497 with linear line equations $\hat{Y}=-28,4515+0,3151 X_{2}+$ $0,5841 X_{3}$. The relative contribution of $X_{2}$ is equal to $25,7965 \%$ and $X_{3}$ is equal to $74,2035 \%$ and the effective contribution of $X_{2}$ of $6,4421 \%$ and $X_{3}$ is equal to $18,5307 \%$.

7. There is a positive and significant relationship between numerical ability, learning independence, and parental attention of students with the results of mathematics learning in seventh-grade students of MTs Muhammadiyah Karangkajen in the odd semester of the 2016/2017 academic year. This is indicated by the F test, namely $F_{\text {count }}>F_{\text {table }}$ or 7,4503 $>2,9912$. Correlation coefficient (R) between numerical ability, learning independence and attention of parents with mathematics learning outcomes of 0.6870 and coefficient of determination $\left(\mathrm{R}^{2}\right)$ of 0.4720 with linear line equations $\hat{Y}=$ $-36,0657+0,3258 X_{1}+0,2120 X_{2}+0,5289 X_{3}$. The relative contribution amount $X_{1}$ is equal to $55,2710 \%, X_{2}$ is equal to $9,1814 \%$ and $X_{3}$ is equal to $35,5476 \%$ and $X_{1}$ effective contribution of $26,0879 \%, X_{2}$ is equal to $4,3336 \%$ and $X_{3}$ is equal to $16,7785 \%$.

\section{REFERENCES}

Fudyartanta, Ki. 2010. Tes Bakat dan Perskalaan Kecerdasan. Yogyakarta: Pustaka Pelajar.

Indarwati, Retno. 2015. Hubungan Kemampuan Numerik, Kemampuan Verbal, dan Perhatian Orang Tua dengan Hasil Belajar Matematika Siswa Kelas VIII Semester I SMP Muhammadiyah 1 Berbah Kabupaten Sleman Tahun Ajaran 2014/2015. Skripsi. Universitas Ahmad Dahlan.

Nurhayati, Eti. 2011. Psikologi Pendidikan Inovatif. Yogyakarta: Pustaka Pelajar.

Slameto. 2010. Belajar dan Faktor - Faktor Yang Mempengaruhinya. Jakarta: Rineka Cipta.

Sugiyono. 2010. Statistika untuk Penelitian. Bandung: Alfabeta.

Walgito, Bimo. 2005. Bimbingan dan Konseling (Studi \& Karir). Yogyakarta: Andi. 